\title{
The Nigerian National Budget and Development Engineering Under Civil Rule
}

\author{
Samuel O. Oyedele \\ Department of Political Science, \\ University of Ilorin, Ilorin, Nigeria \\ Phone: 08054522297, Email: samolaoyedele@gmail.com \\ Accepted: December 11, 2014 \\ Doi:10.5296/ jpag.v4i4.6913 URL: http://dx.doi.org/10.5296/ jpag.v4i4.6913
}

\begin{abstract}
Developed countries of the world always utilize their national budget as viable tools for development engineering. This is because of the potentials of effective budgets for the realization of better lives for the citizenry of such countries. However, the effective management of national budget has remained a mirage in developing countries including Nigeria. This paper examines the performance of national budgets in Nigeria under the present civilian government. The paper discovered dismal failure in the performances of national budgets as a result of irreconcilable disagreement between the Executive and the Legislature leading to delays in budget implementation as well as large corruption among other factors. The paper infers that public budgeting in Nigeria requires radical re-organization and re-orientation coupled with strong political will to make national budgets become powerful instrument for development engineering.
\end{abstract}

Keywords: National budget, Development, Civilian Government, budget failure. 


\section{Introduction}

Nations of the world and other entities usually draw up budgets on annual basis in order to properly guide their finance for developmental purposes. The budget is usually a useful tool for directing and driving of a nation's economy if properly put in place. The management of budgets in terms of their formulation, implementation and monitoring therefore have a lot of implications for the realization of the objectives of budgets to make lives better for the citizenry of a country. The national budgets are even more important to developing countries of the world which are committed to speedy national development. However, the great potential of budgets to serve as instruments of national development cannot be realized if the budget is not executed with utmost commitment and sincerity of purpose.

In many developed countries of the world, the annual national budget had served as a viable approach to development engineering over the years. However, many developing nations have not really achieved the much needed development through budgets. This is as a result of many factors which are primarily human in nature particularly in the area of the formulation and execution of budgets. Governments in such countries have thus recorded dismal budget failure. This could be as a result of lack of budget implementation monitoring mechanisms of its ineffectiveness.

In Nigeria, national budgets, over the years, under military regimes and particularly under the civilian administration have been variously branded to be attractive and appealing to the citizens during their presentations, thereby raising high hopes and expectations on the part of the citizenry. The expectations have been largely in respect of the government matching its pronouncements on budget matters with the needed action or corresponding result to show for it. Consequently, budgetary outcomes have remained far off from the planned targets of government. Indeed, over the years, Federal budgets, whether under Military or civilian administration, have turned out to be a mere ritual rather than the driver of economic development that it ought to be. Consistently, budgetary outcomes have remained far off the mark vis-à-vis the planned targets. ${ }^{1}$

In the light of the above, this paper intends to take a look at annual national budgets in Nigeria, specifically from 1999-2007 and to evaluate their successes or failures in order to determine the extent to which they contributed to the improvement of lives of the Nigerian citizens. It also intends to examine the extent of their viability as an approach to development engineering in the period under review. The paper is divided into four sections. The first section examines the meaning, nature, and significance or utility of budgets in national development planning and implementation. The major conditions necessary for effective budgeting forms the second section while the performance of the national budget in Nigeria is evaluated during the period under study in the third section. The paper ends with the concluding remarks and recommendations.

\subsection{The Meaning, Nature and Significance of National Budgets in National Development Planning and Implementation}

The meaning or definition of the budget has different emphasis by different authors. Ayo ${ }^{2}$ defines a budget as:

A statement of the activities to be carried out by an entity within a specified period and expressed in qualitative terms. It is an estimate for a year ahead of revenues and expenditure chargeable to revenue and parts of its receipts and payments on the capital accounts. It is a means of ensuring effective and efficient resource mobilization, proper management of expenditure, policy adjustments and effective control and co-ordination of economic activities.

\footnotetext{
1 Okeke Marcel, "Budget as Growth Driver" Zenith Economic, Quarterly, Zenithbank.com, January, 2008, p.31.

2 Ayo, S.B., "Implementing a Balanced Budget at the Local Government Level" (paper presented at the National Workshop organized for Local Government Officials, Lagos, Nigeria, (March 1995), p. 7.
} 
The budget has also been viewed as a plan or programme set in financial terms. It is a financial or quantitative statement prepared and approved prior to a defined period in time of the policy to be pursued, during that period for the purpose of attaining given objectives ${ }^{3}$. Simply put therefore, a budget is a plan which is stated in financial terms and meant to cover a time interval in an effort directed at achieving specified goals. In order to achieve a rational basis for financial management in a country, the best approach is to set out clearly, a financial plan indicating how the resources would be mobilized and how they would be utilized.

Such a plan should serve as a blue print for achieving the objectives of any nation. Without this, there is no guarantee that the objectives of a nation can be adequately realized. The financial plan of a country is normally presented in the form of a budget which then forms the basis of the financial operations of the nation. The Budget is a key instrument for macroeconomic management in most economies and its efficacy determines the success of governments in meeting societal goals ${ }^{4}$. The budget is therefore the starting point and for that matter the core of any efficient financial management for national development.

A budget is therefore an accounting document which serves as a control mechanism over a nation or agency as a guide for spending and collection of fund. It is a plan based on past, present and future experiences in addition to the control mechanism. It is a document consisting of both control and plan. Because it is an annual plan, budgeting can be perceived to be a process of taking deliberate measures aimed at moving the relevant economic system from its current state towards a specified desired state. In that case, the revenue and expenditure programmes as well as the fiscal, monetary, trade and other development policies enunciated in a budget are normally designed to move the socio-economic system from its present state towards a desired state 5 . In general term, a budget is an estimate of likely future revenue and expenditure. It includes the use of fiscal policy in order to control the economy.

The significance or utility of the national budget to any country cannot be over-stressed. The national budget is very important to the over-all development of a nation. This is because it is a potential instrument for directing, controlling and evaluating the performance of any government. It is also a tool of economic management as well as a tool for planning. It provides financial plans to be followed by government. It serves as a mechanism for planning towards meeting the various competing demands from government and its agencies or societal needs within the limited or scarce resources available to the government. Thus, it makes for a healthy relationship between ends and scarce means. This implies that it provides a channel for deciding on changes in objective and review of such objectives giving the dynamics of the society. It is also used for improving time, space and material resources allocation. It thus brings about continuity in programme. This continuity makes for effective attainment of certain goals in the short-run or long-run.

The budget is also an instrument for measuring the performance of the economy. This is because it provides adequate control for monitoring expenditure for proper financial management. It is also used to measure the performance of the economy by indicating the performance of the economy in the previous year, making it possible to account for any wide gap between the expected and exact targets projected under the budget. Since a budget translates specific plan objectives into concrete projects and programmes, it makes for the management of on-going activities or projects. This is done by the effective supervision of resources allotted to the accomplishment of natural objective. It is also a mechanism through which specific tasks or projects are carried out effectively and efficiently. It usually considers necessary and mandatory cases to meet statutory requirements and to act as a guide in the running and administration of the various component parts of a nation for national

\footnotetext{
3 Omopariola Olu, "Budgeting for Government Programmes" (UNIFESS course on Tax and Revenue Administration, Lagos, Nigeria, October 6-10, 1986), p.15.

${ }^{4}$ Kwanashie, M. "Connections and Disconnects in Budgeting Information, Issues for Budget Sectoral Analysis in Nigeria" (paper presented at the national workshop at the centre for Democracy and Development, Abuja, Nigeria, February, 2003) p. 12.

5 Ajakaiye Olu "Towards Effective Budgeting under a Democratic System” NCEMA Policy Series Analysis, Vol.5, No 1, October 1998, p.145.
} 
development.

What stands out in the importance of the national budget is that it is usually a means of raising the standard of living of the people of a country. It is thus an important means of gaining or winning the public confidence because it determines how the government should be judged in relation to solving the problems of the society especially under civilian government. This is because, if effectively put into use, the budget enables the government to control the rate of inflation, rate of import and export unemployment rate, tax policy and the rate the development in a nation. And talking about development in a nation, it is imperative to examine briefly, the concept of development.

\section{The Concept of Development}

Development is a complex concept. However, without going into the complexity of development, we hereby view economic development is said to have occurred when per capita income rises and income distribution improves with relative access to education, healthcare, communication, transportation, shelter, production technology and the quality of life improves generally. For instance, Marsh ${ }^{6}$ conceives development as huge changes in the lives of people and societies. It is also a progression from one condition to another. That is, from underdevelopment to development.

Development is also seen as a nation-wide continuous promotion of the well-being and security of persons in such a way that they are constantly able to optimize the realization of their individual potentials. In this wise, national development involves the action of the human resources on the natural resources to produce goods necessary to satisfy the economic needs of the citizenry of a nation. ${ }^{7}$

\section{Conditions For Effective Budgeting}

We have examined the meaning and potentials or utility of national budgets as a tool for national development engineering. It is also important here to stress the need for making the budget work in order to achieve its potentials. It is appropriate to first of all identify the basic features of a good budget.

The starting point for a good budget is that certain features must be noticeable in such a budget. Before a budget can achieve its set objectives, it must possess certain features. First, it must be inclusive enough to capture a complete picture of the financial plan for operating the nation or organization. In other words, income, expenditure, debt services, fixed charges and other related matters must be included in the budget. Second, a good budget must consider the balance between income and expenditure. This involves the maintenance of balance among the various activities of the various units or agencies of government. Huge surpluses or deficit should be avoided. This, the budget should emphasis responsibility by showing those to be responsible for the compilation, review, approval and execution of the budget. Fourth, fiscal control measures should be in place. This will ensure the control and disbursement of available funds as a point of reference for the country. Fifth, a good budget should give room for flexibility. It should take into consideration the possibilities of emergencies which could lead to changes in the original financial plan contained in the budget. Sixth, adequate publicity must be given to budget proposal in order to keep the general public informed of the budget proposals. This will give room for criticisms and suggestions by members of the public on Radio, Television stations, Newspapers and other means of mass communication. Finally, a definite fiscal year must be stated and a good accounting system should be provided in order to bring out the basis upon which incomes and expenditures can be estimated.

\footnotetext{
${ }^{6}$ Marsh, I. "Making Sense in Society (New York: Addison Wesley, Longman, 1996) p.56.

${ }^{7}$ Yusuf Noah, "Globalization and the Challenges of Development" in Hassan, S. (eds), Perspectives on Nation-Building and Development in Nigeria Environmental and Economic Issues (Lagos: Concept Publications Limited, 2008), p.193.
} 


\section{A Review of the Nigeria National Budget (1999-2007)}

As noted earlier, the national budget is an annual financial and economic plan that serves as a vehicle for the mobilization, allocation and management of resources for the good of the citizenry of any country. It therefore has great potentials to serve as development engineering devise in any country. In Nigeria, after decades of military rule, the legitimate expectation of the Nigerian citizens under the civilian government that came into power since 1999 is to expect a reasonable level of what is now commonly called the dividends of democracy. Using the national budget as our point of departure, we now want to see the extent to which the Nigerian national budgets from 1999 to 2007 achieved their set objectives or how they have imparted on the general well being of the majority of Nigerians and their impact on national development in general.

\subsection{Budget Process under Civil Rule}

The 1997 and 1998 national budgets were drawn up and implemented under the military regime of Abdulsalami Abubakar and were regarded as budget of transition. The budgets were not seriously pursued because all attention was placed on the transition programme of the regime. The performances of these budgets were carried on to 1999 when a civilian government came into power. Unlike budgeting under military rule, a distinguishing feature of the presidential system of government is the separation of powers between the executive and the legislative arms of government. It must therefore be noted that the budget process under a civilian government involves a cycle that is composed of the executive preparation stage, the legislative consideration stage, the execution stage and the audit and evaluation stage.

This principle of separation of powers provides some checks and balance against excessive abuse of power. It is expected to be a major departure from the practice under many decades of military rule in the country.

Therefore, the core values of budgeting under civil rule over the practice under military rule involve execution, monitoring and accountability through debate in Parliament. In other words civilian governance offers a more complex environment within which decision about the objectives and resources for implementing the national budgets are made.

The Executive Preparation stage is the stage where the executive branch of government will transmit the general directions for agency request preparations. This is usually done by call circulars through the plan and budget coordinating ministries or agencies. The coordinating Agencies are the Budget office of the Federal Ministry of Finance and the National Planning Commission. The call circular contains guidelines which the agencies are required to follow in preparing their requests for inclusion in the budget. This is followed by a review of the various requests received by the coordinating agencies. This is to ensure that the requests are in accordance or consistent with the policies stated in the call circular. It will also ensure reasonableness of cost and the feasibility of achieving the proposed targets of the various Ministries and Departments. Subsequently, the budget and planning coordinating agencies hold administrative budget hearings in order to ascertain that the guidelines are strictly followed in order to ensure compliance and uniformity. At this stage too, additional justifications for the request may be demanded by the coordinating agencies. Thereafter, each Ministry's requests are further collated and sent to the legislature for further action.

The Executive Preparation stage is followed by the Legislative consideration where the budget proposals received from the executive are subjected to more scrutiny by the various sub-committees of the National Assembly. This usually involves holding of budget hearings during which the various Ministries are required to defend their requests in the budget proposals submitted. This is to assure the legislators that the budget properly reflects the priorities of their constituencies. A committee of the National Assembly will harmonize the various amendments made by the sub-committees and come up with a unified budget for final approval by the President. The President's assent to the budget bill gives it legal status and ready for execution. 


\section{MInstitute Macrothink $_{\text {Int }}^{\text {Intion }}$}

Journal of Public Administration and Governance

ISSN 2161-7104

The Budget Execution stage is the stage where Ministries implement their approved budgets. Spending must begin in line with the approved budget. It is illegal for any Ministry to spend more than the approved budget. Each Ministry must ensure proper monitoring of the relationship between actual expenditure and approved expenditures throughout the fiscal year. At this stage too, various forms of audit exercises are carried out by the office of the Auditor-General of the Federation in order to determine compliance with appropriation and findings are reported to the National Assembly.

Against this background, a proper assessment of the national budgets from $1999-2007$ would be made vis-à-vis their performances in national development. As earlier noted, the 1997 and 1998 national budgets were prepared under the military regime that handed over power to the civilian government in 1999. Thus, the implementation and performances of these budgets were carried on to the civilian government.

In 1999, the government obtained a supplementary budget of N195billion in view of the mid-year assumption of power in 1999. This could be understood in view of the prevailing circumstance of a new government. In the year 2000 draft budget was presented to the National Assembly by the President in November 1999. But five months later, the budget was yet to be passed into a bill or signed into law. The initial total budget estimates submitted to the National Assembly was N470 billion. However, after this initial submission, the President forwarded three separate supplementary budget proposals thereby bringing the new total to N594 billion. However, at the end of the budget scrutiny and amendments at the National Assembly, about N100 biilion had been added to the original submission from the Presidency. This disagreement caused the long delay in the passage of the year 2000 budget into law. This was a major obstacle to the success of that year's budget. This is because, for a budget that was designed to cover a whole year and which represented the core instrument for the implementation of government's programmes and projects, its non-passage during the first half of the budget year already meant that the budget had failed.

The year 2000 budget also recorded large scale imprudence and financial recklessness especially in the area of financial allocations to the members of the national Assembly. For instance, the senate was allocated N996,225,000 for travels and N71,490,000 for utility services remained largely a failure in their formulation, execution and monitoring. For example, haphazard or ineffective implementation could be gleaned from the people which the then Senate indicted over an alleged non-implementation of all Appropriation Acts since the dawn of democracy in 1999.

The implementation of budgets from 1999 to 2002 shows:

that they were not regarded as an article of faith; that the trend shows a virtual slide into financial anarchy... inability to develop its human resources and infrastructure makes it impossible to plan its investments thereby rendering $t$ impossible for the expected inflow of foreign investments into the country. Non-implementation of budget erodes the confidence of the international community in Nigeria. (Report of Senate Committee, 2002). This situation applies for other years under review.

The report added that capital provisions in all the budgets from 1999 to 2002 have always been under-funded while excess spending have always been recorded in the recurrent budget. For instance, although the year 2000 budget made provision for an expenditure profile of N6.2 billion, actual expenditure was N31 billion. In other words, illegal expenditure of public funds affects budgetary performance in the last ten years in Nigeria. Although between 1999 and 2002, the price of crude oil, which is the main source of budgetary funding has not fallen below the budgeted price, the performance of budgets in the same period has been very dismal, making it impossible for any meaningful development in the country.

Another problem is the release of budgeted funds. The policy of government was that releases of budgeted funds were to be on a quarterly basis but this policy had been observed more in the breach than in compliance, resulting in epileptic and haphazard releases of funds into the economy. 
Time is very important in budgeting because a budget delayed is equivalent to projects denied. In the past ten years, and especially between 1999 and 2007, a lot of bickering that usually accompany national budgets in the Senate and House of Representatives and the disagreements between the Legislature and the Executive over certain indices to be employed in determining the budget estimate have led to delays in passing most budgets particularly since 1999 at the commencement of democratic governance in Nigeria.

Another issue that has bedeviled effective implementation of budgets is the late or non-release of cash backings for budgeted items. It is common to hear complaints of non-release of funds to execute projects in good time, leaving no room to undertake any meaningful development or implementation of budgeted items. This has led to rushing of projects, lack of monitoring, leading to corruption.

Corruption is another major cause of budget failure in Nigeria particularly in the last ten years, N19.5 billion aviation intervention fund, has been reported to have been diverted to other uses such as campaign expenses. In the power sector, billions of dollars have been spent in the past few years with noting to show for it. Large scale diversion of huge sums of money budgeted for development programmes especially on infrastructural facilities have been wasted.

Bearing in mind that the national budgetary provisions in the last eight years in Nigeria had increased from billions of Naira to trillions of Naira, it is necessary to asses the performances of these budgets in relation to their contribution to national development vis-a-vis the reality on ground. In order to do this objectively, there is the need to examine the situations in the key sectors of the country's economy. This is because the national budget is an instrument for measuring the performance of the economy. The following issues shall be examined:

a. Inflation: The rate of inflation in Nigeria in 1999 and 2000 were single digits. However, there was an upturn in the trend from 6.9 per cent in year 2000 to 19.9 per cent in year 2002 . It subsided to 10.7 per cent in $2003^{8}$. The federal government fiscal deficit in 2002 was N30.4 billion which was 5.1 per cent of the Gross Domestic Products. This situation remains the same till 2007. Inflation erodes real incomes, weakens purchasing power, undermines the welfare of the people, detrimental to investment and generally retards economic development. Closely linked to inflation is poverty. Inflation rate today in Nigeria stands at 9.7 per cent.

b. Poverty: According to the Federal Office of Statistics (1999) rural poverty increased from 17.6 per cent to 55.2 per cent. The poverty situation in Nigeria is precarious not only in income poverty but also in terms of food poverty. On income poverty, the nation witnessed a worsening income inequality, while on food poverty, the proportion of the underweight children stood at 30.7 per cent in 1999. The figure for rural food poverty stood at 34.1 per cent while that of urban food poverty was 21.7 per cent. Similarly, Nigeria's rank in the Human Development Index remained low, being the $152^{\text {nd }}$ out of 175 countries. This low HGI score reflects the situation with regard to poor access to basic social services in the country ${ }^{9}$. The use of socio-economic indicators like per capital income, life expectancy at birth, access to healthcare services, safe water, education, sanitation facilities and electricity, also depicts the extent of poverty in Nigeria.

The promise to ensure poverty alleviation could not be achieved. NEEDS, the government's glorified project for poverty alleviation, in the end was a needless, disappointing distraction ${ }^{10}$

b. Unemployment: Unemployment has remained a major problem with government in Nigeria. Many citizens are roaming the streets searching for any available job to take. A lot of

\footnotetext{
${ }^{8}$ Obaja Theophilus "Still Economy for the Year 2003" Labour Rights, Vol. 4, No. 4, October - December, 2003, p. 26.

9 UNDP, World Development Report, Washington DC. United Nations, 2004, p. 201.

10 Nigerian Tribune Editorial Comment, Nigerian Tribune, 29 May, 2007, p. 6.
} 
businesses are collapsing everyday due to the harsh economic climate, wit local and multi-national establishments laying off thousands of Nigerians into the labour market, who in most cases, end up in crime. Indeed, in 2006, the former Minister of Education painted a graphic representation of the unemployment situation in Nigeria when she declared that seven out of ten Nigerian graduates are unemployed as a result, by 2020, we may have a significant proportion of highly skilled trained criminals if nothing positive is done.

c. Housing for Nigerians: The housing situation in the contrary in the past ten years is also pathetic. For instance, the Minister for Housing revealed recently that over 70 per cent of Nigerians don't have proper housing ${ }^{11}$.

d. Transportation/Road Construction: It has just been revealed by the ex-Director of Federal Highways, Mr. Charles Unuigbe of Works that a total sum of 415 billion Naira was spent on road construction between 1999 and $2007^{12}$. But the reality on ground is that major roads in Nigeria today are in a state of disrepair.

e. Agriculture: Agriculture remains the mainstay of the economy, because it engages over 70 per cent of the active labour force and accounting for about $40 \%$ of the Gross Domestic Product. However, within the period of ten years now, the sector had continued to face problems of poor rural infrastructure, poor distribution of both agricultural produce and inputs, and high costs of farm inputs $^{13}$. The problematic situation of the Nation's Agriculture is responsible for the food crisis being experienced in Nigeria today.

\section{Conclusion}

An overall assessment of the developmental situation in Nigeria in the last decade reveals negative growth in the economy. For instance, the International Monetary Fund (IMF) in its 2002 Report stated that the economy of Nigeria shrunk by $0.9 \%$ in the year. This negative growth belies the huge revenue from oil. A national Newspaper editorial captured the situation thus:

The economy, to all intents and purposes, run rudderless robbed of the deft and steady hands of creative managers. Policy uncertainty, executive arbitrariness, unsustainable expansionary spending, and wastages are the defining characteristics of what could pas for monetary and fiscal policies. The logical effects are there for all to see; decaying infrastructure, growing unemployment, deepening poverty, increasing crime and insecurity. ${ }^{14}$

The performances of the national budget in Nigeria during the period under study have recorded persistence budget failures. This can be traced to a number of reasons. Some of these include inherent government limits in the Public Policy Process, limited capacity or lack of integrity among the makers, designers and implementers of the budget. This results in gaps between budget proposals and implementation. Others are the absence or inadequacies and obstacles in budget implementation process, as well as absence of honest evaluations of previous failed budgets in order to guide other budget exercises.

The budget office undoubtedly has also failed in its duty of effectively tracking capital projects. This underscores why ministry officials found it easy to pad a new budget with previous year's already completed works. The Federal legislators could not absolve themselves from short-comings in this regard, since what happen and may still happen is a reflection of their failure in the discharge of their oversight functions. ${ }^{15}$

On the other side are political issues. As a result of the adoption of the Presidential system in

\footnotetext{
${ }^{11}$ The Punch, $2^{\text {nd }}$ July, 2008, p. 24.

12 The Nigerian Compass, $3^{\text {rd }}$ July, 2008, p.18

13 Dunmoye, R.A. "The Political Economy of Nigeria is the Year of Civilian to Democratic Transition in Hassan Saliu (ed.),

Nigeria under Democratic Rule (1999 - 2003), Ibadan: University Press Plc, 2004, p. 158.

14 This Day Newspaper, October 22, 2002, p.15

15 The Nation Newspaper, April 9, 2010, p. 21.
} 
Nigeria, there is a clear practice of separation of powers under which he Executive appropriates, while the Legislature legislates. However, this practice has remained problematic in Nigeria during the period under study. This is because one arm of government had invaded the other on budget issues. For instance, over the years, the legislature introduced programmes such as constituency projects, legislative offices and others perhaps with the aim of muscling the executive into ceding part of its powers to it by insisting that they should be allowed to execute those projects which they have included in the budget.

Consequently, this became a source of constant disagreement and argument between the Executive and the legislature leading to delays in the passage of budget bills into laws. The issue however is that, because the Executive and the Legislature are elected representatives of the people, they should be working together in such a manner that while the executive proposes, the legislature should appropriate accordingly ${ }^{16}$.

From the above, it is clear that the Nigerian economy, despite its vast human and natural resources, has not manifested the required managerial and structural changes that would guarantee rapid and sustainable growth conducive to an acceptable minimum standard of living. The productive and technology bases, which are the prime movers of the economy, are weak, obsolete, disperse and lack sectoral linkages ${ }^{17}$. As a result of the weak economic base of the country in the past eight years development is at a very low level in the country. To all intents and purposes, it is without doubt that we concluded that the national budgets have failed to be a viable approach to development in Nigeria, particularly in the period under study.

\section{Bibliography}

1. Okeke Marcel, "Budget as Growth Driver" Zenith Economic, Quarterly, Zenithbank.com, January, 2008, p.31.

2. Ayo, S.B., "Implementing a Balanced Budget at the Local Government Level" (paper presented at the National Workshop organized for Local Government Officials, Lagos, Nigeria, (March 1995), p. 7.

3. Omopariola Olu, "Budgeting for Government Programmes" (UNIFESS course on Tax and Revenue Administration, Lagos, Nigeria, October 6-10, 1986), p.15.

4. Kwanashie, M. "Connections and Disconnects in Budgeting Information, Issues for Budget Sectoral Analysis in Nigeria" (paper presented at the national workshop at the centre for Democracy and Development, Abuja, Nigeria, February, 2003) p. 12.

5. Ajakaiye Olu "Towards Effective Budgeting under a Democratic System" NCEMA Policy Series Analysis, Vol.5, No 1, October 1988, p.145.

6. Marsh, I. "Making Sense in Society (New York: Addison Wesley, Longman, 1996) p.56.

7. Yusuf Noah, "Globalization and the Challenges of Development" in Hassan, S. (eds), Perspectives on Nation-Building and Development in Nigeria Environmental and Economic Issues (Lagos: Concept Publications Limited, 2008), p.193.

8. Obaja Theophilus "Still Economy for the Year 2003" Labour Rights, Vol. 4, No. 4, October - December, 2003, p. 26.

\footnotetext{
${ }^{16}$ Nigeria Economic Summit Group "Budget: How Presidency, National Assembly should Collaborate", The Nation, $3{ }^{\text {rd }}$ May, 2010, p. 24.

${ }^{17}$ Dunmoye, R.A. "The Political Economy of Nigeria is the Year of Civilian to Democratic Transition in Hassan Saliu (ed.), Nigeria under Democratic Rule (1999 - 2003), Ibadan: University Press Plc, 2004, p. 158.
} 
9. UNDP, World Development Report, Washington DC. United Nations, 2004, p. 201.

10.Dunmoye, R.A. "The Political Economy of Nigeria is the Year of Civilian to Democratic Transition in Hassan Saliu (ed.), Nigeria under Democratic Rule (1999 2003), Ibadan: University Press Plc, 2004, p. 158.

11.Nigerian Tribune Editorial Comment, Nigerian Tribune, 29 May, 2007, p. 6.

12. The Punch, $2^{\text {nd }}$ July, 2008, p. 24.

13. The Nigerian Compass, $3^{\text {rd }}$ July, 2008, p.18

14.Dunmoye, R.A. "The Political Economy of Nigeria is the Year of Civilian to Democratic Transition in Hassan Saliu (ed.), Nigeria under Democratic Rule (1999 2003), Ibadan: University Press Plc, 2004, p. 158.

15. This Day Newspaper, October 22, 2002, p.15

16. The Nation Newspaper, April 9, 2010, p. 21.

17. Nigeria Economic Summit Group "Budget: How Presidency, National Assembly should Collaborate", The Nation, $3^{\text {rd }}$ May, 2010, p. 24.

18.Dunmoye, R.A. "The Political Economy of Nigeria is the Year of Civilian to Democratic Transition in Hassan Saliu (ed.), Nigeria under Democratic Rule (1999 2003), Ibadan: University Press Plc, 2004, p. 158. 